\title{
Degnen B. C. Knutz i Stenbjerg og hans oplevelser under treårskrigen.
}

\section{Af Holger Hjelholt.}

I den levnedsskildring, som jeg i sin tid gav i „Sønderjydske Aarbøger" (1926) af pastor Chr. Christiansen i Medelby, anførte jeg en udtalelse af denne om, at årene $1848-50 \mathrm{blev}$ en fristelsens og forførelses tid for "så mange iblandt os herovre“. Det gik jo sådan, at både $\mathrm{i}$ embedsstanden og i befolkningen svigtede mange - særlig i Mellem- og Sydslesvig - deres troskab mod konge og fædreland, enten det nu skyldtes den slesvig-holstenske bevægelses egen styrke eller et holstensk eller tysk tryk.

På denne baggrund lyser med dobbelt glans de mænd, der urokkelig $\mathrm{cg}$ uforfærdet holdt fast ved gammel nedarvet kongetroskab og holdt stand mod den herskende stemnings tryk. Om en af disse mænd, en "simpel“ degn, skal de følgende linjer fortælle.

B оу e Cornils Knutz stammer fra Ejdersted, født i Oldenswort den 31 . august 1787. Da han var 3 år gammel, drog forældrene til Welt, hvor han gik i skole til omkring 1806. Da, scm han skriver $i$ en senere beretning om sit liv, præsten og degnen troede, ,at jeg var født til at blive en skolelærer, jeg selv også følte tilbøjelighed til skolevæsenet, så besøgte jeg seminariet i Kiel, lidt efter påske 1806".

Kiel var ikke dengang, sådan som det senere blev, det arnested, hvor man indsugede slesvig-holstenske lærdomme og had til alt, hvad der var dansk. Tværtimod rådede der på denne tid en patriotisk stemning, og da ufreden med England det følgende år brød ud, forenede i Kiel frivillige - studenter, seminarister og kommisser - sig om dannelsen af et jægerkorps, der talte omkring 150 mand. Blandt korpsets seminarister var også 
Knutz. Våbenøvelserne varede 5-6 uger, og korpset drog forskellige gange på vagt.

Kort før påske 1808 blev Knutz dimitteret fra seminariet, og den 24. april samme år ansattes han - altså knap 21 år gammel - som substitut (medhjælper) ved Sørup skole i Angel. Den gamle degn her havde, skriver Knutz, hver dag nok at gøre med sin store gård i Svendsby!

I Sørup var K. tre år, hvorefter han forfremmedes til lærer i Kalleby i Kværn sogn, hvor han forblev de følgende tre år. Hus og jord bortlejede han og lejede sig som ugift ind hos en bonde, hvor han fik kost og logi. Et års tid efter ankomsten til Kværn blev degnen i Stenbjerg, Seehusen, meget syg, og Knutz kom da til at hjælpe ham ved hans forretninger i kirken og ved begravelser, blev herved en hyppig gæst $i$ hans hus, og re.. sultatet blev en forlovelse med den ældste datter, Magdalena (født i Stenbjerg, ca. 1792). Da Seehusen ikke blev i stand til at forestå sit embede, onskede han naturligvis meget at få svigersønnen til eftermand, hvad der også lykkedes. Den 24. april 1814 fejredes brylluppet, og kort efter ansattes Knutz som degn og lærer i Stenbjerg. Her skulle han virke som lærer næsten et halvt århundrede.

Såremt det slesvig-holstenske oprør i marts 1848 ikke var brudt ud, var der næppe blevet stort mere at fortælle om Knutz end om så mangen anden samvittighedsfuld og pligtopfyldende degn og skolelærer. Han - som de fleste andre af os mennesker - var i det huslige liv ude for såvel medgang som modgang. Af 8 børn døde de tre forholdsvis unge, de to begravedes på Stenbjerg kirkegård, den tredje, en søn, døde på et skib ved Amerikas vestkyst og begravedes på sømandsvis i havet. - Et nyt degnehus byggedes i 1830 i stedet for det gamle, der ikke var $i$ stand til at værne beboerne mod kulde, blæst og regn. Bygningen kostede 1600 rdl., og den 26. oktober kunde degnen og hans familie, dengang 13 personer, 
flytte ind "under ydmyg bøn og alvorlige tanker". Ligeledes sikolehuset måtte udvides. Til 1835 var skolen delt $i$ to klasser, hvoraf hovedklassen bestod af 4 og elementarklassen af 3 fag. Men da var børnenes tal så stort, at man så sig nødt til at slå klasserne sammen. I 1842, da der i alt var 150 børn, måtte man dog bygge 3 fag til og dele børnene i 2 afdelinger, der hver fik 5 fag af skolehuset at råde over.

Ja, disse oplysninger gør selvsagt ikke krav på mere end lidt sognehistorisk interesse. Men i 1848 brød de revolutionære bevægelser løs rundt om i Europa, forplantede sig også til det danske monarki, og i Kiel tændtes oprørsflammen den 24 . marts. Også i Stenbjerg sluttede mange beboere sig til insurgenterne, og de dansksindede led megen forhånelse og skade. Modparten kaldte dem dosmere, fordi de ikke valgte vejen mod syd, og forsikrede dem om, at ingen dansk soldat mere skulde betræde Sønderjyllands jord. Til "dosmerne“ hørte den gamle degn Knutz, og ved sin urokkelige fastholdelse af konge- og siatstroskab kom han, tør man vist sige, til at spille en rolle, lille eller større, ikke blot i sognehistorien, men i landets historie. Han blev et smukt eksempel på en mand, der stod fast i en fristelsens og forførelses tid.

Allerede i april 1848 havde danske soldater jo betrådt Slesvigs jord, men kort efter fordrev påskeslaget ved Slesvig dem, og der skulde nu gå en for de dansksindede langsommelig tid hen, før de kom igen. Forud for dem kom til Nordslesvig og en del af Mellemslesvig svenske og norske soldater i sommeren 1849. Ved en overenskomst i Berlin i juli 1849 mellem Danmark og Preussen var det nemlig blevet bestemt, at svenske og norske tropper skulde besætte Sønderjylland nord for en linje, der gik mellem et punkt på østkysten nær ved og sydøst for Flensborg og et punkt på vestkysten, nordvest for Tønder. Landet syd for denne „demarkationslinje“ skulde preussiske tropper besætte. Hele Sønderjylland skulde styres af en kom- 
mission på tre medlemmer, hvoraf Danmark valgte et, Preussen et, og det tredje valgtes af England som opmand i tilfæelde af meningsforskel mellem de to andre.

Denne bestyrelseskommission blev i slutningen af august 1849 indsat i Flensborg. Til medlemmer havde den danske regering udnævnt kabinetssekretær F. F. Tillisch, den preussiske den konservative embedsmand Botho Heinrich, greve af Eulenburg, medens det af England valgte medlem var oberst Lloyd Hodges.

Ifølge demarkationslinjen kom syv angelske sogne til at ligge nord for denne. Det var følgende: Adelby, Munkbrarup, I.yksborg, Grumtofte, Nykirke, Kværn og Stenbjerg. Det var godt for de derboende dansksindede beboere, men naturligvis mindre opmuntrende for de tysksindede, der havde skældt danskerne ud for dosmere og nu foreløbig måtte tåle synet af svenske og norske soldater. De tysksindede skyndte sig med at få en deputation sendt til Berlin for hos Frederik Vilhelm IV at klage over, at deres sogne var kommet til at ligge i den nordlige halvdel. Deputationens ordfører var den fra Holsten stammende pastor G. Schmidt i Grumtofte, og har man bevaret en smule humoristisk indstilling over for propaganda - det kan være svært nok i tider som vore - er referatet af præstens tale til Preusserkongen en virkelig fornøjelig læsning. Ikke blot de mere intelligente, men også de bedre blandt angelboerne var, hævdede Schmidt, næsten uden undtagelse tysksindede. Folkets dannelse vilde gå til grunde under dansk herredømme og danskerne vilde gøre angelboerne til jyder: „På hvilket trin d iss e står, er bekendt". Den danske propaganda var, som bekendt, „et væv af løgn og bedrageri, af forræderi, bagvadskelse og undertrykkelse, af nederdrægtigheder af al slags". Nå, pastor Schmidt havde jo studeret i Kiel, om dette nu kan tjene ham som undskyldning.

Bestyrelseskommissionens herredømme skulde egentlig have strakt sig over hele Slesvig, altså også Sydslesvig. Imidler- 
tid fik kommissionen ikke den støtte hos de preussiske besættelsestropper, som var forudsat $i$ overenskomsten mellem Danmark og Preussen, og det lykkedes derfor oprørsregeringen i Kiel at udvide sit styre til store dele af Sydslesvig. I foråret 1850 meddelte F. C. F. Jacobsen, som af oprørsregeringen var blevet udnævnt til amtmand i Flensborg amt, at han atter overtog dette embede, skønt bestyrelseskommissionen havde indsat en anden, Warnstedt. Jacobsen tog ophold i Sørup, syd for demarkationslinjen, og han prøvede oven i købet herfra at gøre sin myndighed gældende $\mathrm{i}$ den del af amtet, der iå nord for linjen. Også til denne del udsendte han sine bekendtgørelser, for at de her skulde offentliggøres.

2. påskedag 1850 , d. v. s. den 1. april, overleverede præsten i Stenbjerg, en holstener, tre bekendtgørelser (publicanda) fra Jacobsen til degnen Knutz, for at han skulde offentliggøre dem. Men Knutz sagde nej. Vi gengiver nu hans egen beretning om dette mindeværdige optrin og om, hvad der videre tildrog sig:

„Efter gudstjenesten sagde jeg menigheden, at jeg ikke vilde og kunde publicere dem. Straks efter middag sendte præsten sin svend for at hente publicanderne, men han fik dem ikke. En kort tid derefter kom 6 tyske (d. v. s. tysksindede) bønder, incl. de 2 jurater (kirkeværger), for at spørge, hvorfor jeg ikke havde oplæst disse bekendtgørelser i kirken, de måtte dog vide, hvorefter de skulde rette sig; jeg fik dog betaling for at oplæse dem i kirken. Mit svar var, at jeg ifølge min bestalling var Hans kongelige Majestæt troskab og lydighed skyldig, at Guds ord og min samvittighed sagde mig det samme, og at jeg ikke vilde adlyde hans fjende, hvad der end vilde ske. Dermed gik de, uden at de fik publicanderne i deres hænder. Den anden dag leverede jeg bekendtgørelserne til amtmand Warnstedt og efter hans onske til kammerherre Tillisch. Derefter gik jeg hjem og tænkte ikke på nogen fare.

Dog jeg havde forregnet mig; thi søndag eftermiddag, d. 7. april, fik jeg et besøg af den Sørupper amtmand, ledsaget af en 
bevæbnet politibetjent. Herren havde taget det ilde op, at en gammel degn havde været så dristig at modsætte sig hans befalinger. Jeg sad, som han bevæbnet betrådte gårdsrummet, bag ovnen og læste. Min kone og datre blev ham først vàr. De blev forskrækkede og tilskyndte mig til bortfjernelse. Jeg slap lykkelig bort. Jacobsen gik ind i stuen, hvor mine to døtre var blevne til stede. På hans spørgsmål, hvor jeg var, svarede en af dem, jeg var gået ud, hvorhen kunde hun ikke sige ham. På det andet spørgsmål: hvor bekendtgørelserne fra ham var blevne af? fulgte til svar: det vidste hun heller ikke. Efter at han havde befalet min datter, at hun skulde sige mig fra ham, at, når jeg vilde komme til ham i Sørup næste onsdag, d. 10. april, så vilde han forfare nådig mod mig, men vilde jeg ikke adlyde ham og komme, så skulde det ikke gå mig vel, thi han havde magten, bortfjernede [de] sig derpå; Jacobsen vest på til præsten, den anden syd på. Da denne sidste engang så, at to mænd gik ind $\mathrm{i}$ mit hus, tænkte han måske, at den ene vel kunde være mig. Hurtig kom han tilbage og spurgte, om jeg nu var kommen hjem. Jeg var, men det hed dog nej! og han gik sin vej igen.

En skoledreng havde set Jacobsen ved kirken og tillige, at han gik herned. Drengen løb i firspring til en nabo og jamrede: amtmanden var gået til degnen at tage ham fangen, de skulde dog hjælpe degnen! Som en løbeild gik denne efterretning gennem byen, og inden kort tid var et halvt hundrede mennesker strømmet sammen, nogle med bøsser. Det skete, som amtmanden var gået bort. I folkets midte var jeg nu sikker nok. To personer gik nu op i præstegården for at sige Jacobsen fra mig, at jeg nu var kommen hjem: vilde han tale med mig, så kunde det ske. Han selv blev borte, men hans politibetjent kom, hilsende fra sin herre, om jeg ikke vilde være så god og møde ham i kroen ved kirken. For denne ære takkede jeg [d. v.s. betakkede mig], hvorpå manden igen gik. Da han ved sin bortgang så de mange mennesker i skolen, kunde han vel se, at her ikke 
var mere at gøre. Derfor satte hans herre med sekretæren Westedt sig snarest muligt på vognen og begav sig hinsides demarkationslinien, hvor de var komne fra.

Han havde valgt denne dag til sit overfald, fordi han efter [beretning af] en om lørdagen herhid udsendt spion vidste, at de lojale beboere var forsamlede ved Streichmühle [Strygmolle i Grumtofte sogn]. Havde de været til stede, så kunde han måske let være bleven til fange; men nu var de fleste unge, utilforladelige mennesker. Frygten for tyskere, som boede iblandt og omkring os, og for Sørupper gendarmerne, hvilke var bekendte som rå og ryggesløse mennesker, holdt også forsamlingen tilbage fra at gribe ham. Natten efter denne dag holdtes vagt i skolen af 5-6 mænd. Ja, i de næste dage havde jeg bestandig en terzerol i lommen og var i hvert øjeblik beredt til at tage flugten ud af skolen.

Om onsdagen efter den omtalte affære blev det rygte udspredt, at en stor fare svævede over vore hoveder. At Sørupper gendarmeriet vilde komme og tugte os såkaldte landsforrædere, blev sagt, og antaget for vist. Mine naboer rådede mig til bortfjernelse, og efter [at] jeg havde indsendt en kort beretning til amthuset om, hvad der var sket her, ledsaget med en ansøgning om militær beskyttelse ved svenske tropper, drog jeg, i stedet for at gå til Sørup den dag, nord på til min søn i Rinkenæs. Efter nogle dages ophold der rejste jeg til Flensborg for at tale med kammerherre v. Tillisch. Ifølge hans ønske gik jeg cgså til grev Eulenburg og fortalte ham historien.

Denne [Eulenburg] kom om eftermiddagen til Tillisch, hvor jeg også skulde indstille mig. På mit spørgsmål, hvad jeg havde at gøre, når [hvis] oprørsmanden afsatte mig, svarede Eulenburg, idet han klappede mig på skulderen: Alter Herr, ich glaube nicht, dass dies geschieht; sollte es indess der Fall sein, so seien Sie nur unbesorgt, Sie sollen Nichts dabei verlieren.

I Flensborg fortalte man, at et detachement svenskere for nogle dage siden var marcheret til Stenbjerg, men allerede 
kommet tilbage. Omendskønt den svenske general ikke gerne dislocerede eller adspredte sine tropper for meget, så havde dog endelig amtmandens bøn bevæget ham dertil. Nogle dage efter min hjemkomst kom svenskerne igen; de formerede kæde nord for demarkationslinjen fra Flensborg af; Bjerggade og efterhånden flere byer i sognet erholdt indkvartering. Nu var vi meget fornøjede. De lojale indvånere så gerne de gode mennesker. Omtrent fra midten af april indtil 15. juli vedvarede indkvarteringen af de nævnte tropper hos os.

Men desværre, efter våbenstilstanden [d. v. s. fredstraktaten af 2. juli 1850 med tilhørende protokol mellem Danmark og Preussen] kunde de ikke længere forblive her. Den 15. juli drog kommandoet til Flensborg igen for at forlade Slesvig og marchere hjemad. Hvad skulde vi stakkels forladte nu gøre?! Jacobsen var endnu i Sørup med sin bande. Til Norden satte vi nu vort håb. Et par dage før svenskens tilbagetog skrev jeg til generalkommandoen i Sønderborg en kort skildring om sagens tilstand og faren, for hvilken kongens tro undersåtter blev udsat, når svenskerne forlod os; tillige bad jeg underdanig om, at, om muligt, 1 eller 2 kanonbåde måtte blive henlagte ved stranden, og at mandskabet undertiden måtte patrouillere op ad byen. Manden, som overbragte min skrivelse, kom tilbage med det mundtlige svar, at dansken, ifølge våbenstilstands-konventionen, ikke var i stand til at gøre noget før 17. juli.

Frygten drev mig nu atter til flugt; men ikke alene mig, også mange i sognet, gamle og unge, rige og fattige, vel 100 personer sluttede sig til svenskerne og drog d. 15. juli om morgenen tidlig med dem både til vogns og fods ad Flensborg [til]

Den 16. eller 17. juli gjorde nogle gode venner og jeg en tur til Rinkenæs, til min søn, for at se, om den danske armee, hvorefter [vi] længtes, vilde rykke ind. Vi var så heldige at hilse [på] de første batailloner (12. og 13.) samt nogle jægere, hvilke var detacherede for at demolere pallisaderne ved Kobbermøllen. Tropperne kom indmarcherende helt grå af støv, ikke i 
parademarch, nej, geledderne var opløste, frakkerne opknappede, halsbind og halstørklæde afløste, huerne skubbede bag ; nakken, og hvert øjeblik for hånden med lommetørklædet hen over det glødende ansigt og de røde, smertende øjne. En udmattet jæger lå halvdød i grøften. Fruentimmerne vederkvægede ham, så godt de kunde; dog, den næste morgen var han på benene igen. Næste morgen begyndte marchen til Flensborg, og vort lille selskab kørte ligeledes retur derhen. Først måtte vi ikke køre forud, dog blev det os efter et kort ophold tilladt.

I byen Flensborg blev vi til fredag eftermiddag [19. juli], og vi længtes nu efter at komme til hjemmet. Rolig kørte og gik selskabet indtil Hatlund. Nogle fodgængere havde i Bøttchers hus fået en læskedrik. De kom hurtig løbende til vejen nord for byen og fortalte, at der cm morgenen samme dag endnu havde været tyske gendarmer i Kværn præstegård og befalet jomfruen der at rømme huset inden få timer.

Ligefrem hjemad turde vi under disse omstændigheder ikke vove os. Hvorhen nu? Efter en kort rådslagning tog vi hurtig til Habernis [Havernæs]; fra denne by kunde vi gå langs med stranden til Stenbjerghav. Dér lå et dansk krigsskib til vor beskyttelse.

Herved vil jeg tilføje den bemærkning, at ifølge [som resultat af] skrivelsen til generalkommandoen var [der] straks gået en damper fra Sønderborg til Neustadt i Holsten med befaling, at barkskibet Saga, som lå der, skulde gå under sejl og lægge sig ved Stenbjerghav. Dette skete allerede mandag aften [15. juli], da vi rejste om morgenen. Kommandøren havde bekendtgjort, at enhver, som ikke troede sig sikker, kunde komme om bord hos ham. Skade, at vi ikke vidste dette, førend vi drog afsted.

Natten mellem fredagen og lørdagen sov jeg ved Stenbjerghav; flere gik om bord. Lørdagen kom jeg hjem.

Ganske tryg var ingen endnu. Selv befalingsmanden på skibet turde ikke lade patrouillen gå op til Stenbjerg by. 
Næppe var vi komne lidt til ro, da blev atter det rygte udspredt, at tyske gendarmer nærmede sig Stenbjerg østen fra. Jeg ud i marken i største hast! To bønder kom mig der meget forbavset i møde; det gik i en fart over gærder og volde. Undertiden blev vi stående for at høre [lytte]. Pludselig slog hornets klang til vore oren. Gud.... nu har de taget min søn og fører ham bort med sig, sagde den ene forbitret. I nærheden af Gingtoft skiltes vi ad. Begge blev natten over under fri himmel og skjulte sig i kornet. Jeg gik lidt videre for at erfare, om den blæsen kom fra ven eller fjende. En dreng, som havde været ved stranden, fortalte nu, at patrouillen fra skibet havde blæst.

Forskellige nætter i denne uge [formentlig ugen 21.-27. juli] kamperede mange under âben himmel, den ene $i$ kornet, den anden i en høstak.

Hermed sluttes Stenbjerg lojale indvåneres trængsel.

Den danske armee trængte efterhånden mere og mere frem og rensede hertugdømmet for oprørere. Bladet havde nu vendt sig, og turen kom nu til dem at flygte. Embedsmænd, både gejstlige og verdslige, skyndte sig syd på i det faste håb, at de snart vilde komme tilbage og på det hårdeste gå til værks mod de troblevne. Dog mennesket spår, men Gud rå'r! Deres tanker var ikke hans!"

Som Knutz rigtig bemærker, flygtede de oprørske embedsmænd bort for den fremrykkende danske hær i den tro, at det ikke vilde vare så længe, inden de atter kunde vende tilbage. En lille halv menneskealder skulde dog gå hen, før dette blev tilfældet, og i dette tidsrum var hele Sønderjylland underlagt et dansk styre, et styre, der mere eller mindre konsekvent satte sig det mål at støtte og fremhjælpe landsdelens danskhed. Et meget vigtigt led $i$ disse bestræbelser var den ordning af de officielle sprogforhold i Mellemslesvig, som blev truffet allerede $\mathrm{i}$ februar og marts 1851 under Tillisch, der var blevet ud- 
nævnt til overordentlig regeringskommissær for Slesvig. Ordningen gik ud på at indføre dansk som undervisningssprog i skolerne i de endnu overvejende dansktalende landsogne. Tysk beholdtes imidlertid som en af de væsentlige undervisningsgenstande. I kirkerne skulde der afvekslende prædikes på dansk og tysk.

For Knutz var det, som han skriver, umuligt straks at undervise på dansk, da han var opdraget og dannet på tysk og sjælden havde hørt, ja mindre talt et dansk ord, en udtalelse, der egentlig virker lidt mærkelig. Men, føjer han til, det skortede ham ikke på vilje til at adlyde regeringens befaling, og ved megen møje og anstrengelse bragte han det også til at kunne både tale og skrive dansk, selv om ikke helt grammatisk rigtigt. Germanismerne i den ovenfor gengivne fremstilling vidner herom. I juni 1851 ansattes desuden en dansk seminarist som hjælpelærer ved skolen.

Kort tid efter oprørets undertrykkelse skulde Knutz høste belønningen for sin kongetro adfærd i trængslens dage. Den 6. oktober 1851 udnævnte kongen ham til dannebrogsmand, og søndagen den 19. oktober fik han sølvkorset overrakt af amtmanden over Flensborg amt, F. H. Wolfhagen. Det skete ved en festlighed i Stenbjerg skole, hvor skolebørnene havde smykket skolestuen med blomster, og hvor et stort tal af beboerne havde indfundet sig. Efter amtmandens tale holdt Knutz dybt rørt en takketale, hvor han naturligt nok dvælede ved den overståede trængselstid, og hvor han endte med at minde børnene om stedse at være deres konge tro og erindrede om bibelsproget: Frygt Gud og ær kongen! — De to første vers af "Gud signe vor konge god!" blev afsungne, og et trefoldigt Leve kongen! blev udbragt. - I „Flensburger Zeitung“, hvor festligheden refereres, hævdes det, at det var langt den største del af indbyggerne i Stenbjerg, der under oprøret var forblevet kongetro.

En anden stor og glædelig oplevelse blev Knutz til del ved 
hans j0-års jubilæum, den 24. april 1858. Ved den højtidelighed, som i den anledning afholdtes i skolen, indfandt kirkevisitatorerne for Flensborg amt sig, amtmanden, baron WedellWedellsborg, og provsten, Aleth Hansen. I kongens navn overrakte amtmanden Knutz et kostbart guldlommeur med indskriften: Til Boye Cornils Knutz i anledning af hans 50-årige jubilæum, og prydet med kongens navnechiffer, om hvilket var anbragt ordene fra en af Davids salmer: Mine øjne ser efter de trofaste i landet. — Både amtmanden og provsten holdt naturligvis taler, men Knutz selv blev over den kongelige gave, som han siger, så befippet og ør i hovedet, at han ikke dristede sig til at sige noget, før de høje herrer havde forladt skolestuen og var gået til præstegården. Senere holdt præsten, H. Bech, her festmåltid for visitatorerne, Knutz og hans familie, medens forsamlingen i skolen gjorde sig til gode med punch og smørrebrød, så alle blev meget glade og fornøjede! - Også beboerne havde skænket Knutz en smuk gave til jubilæet.

Da pastor Bech i februar 1858 havde henledt provstens opmærksomhed på det forerstående jubilæum, havide han dołs samtidig fremhævet, at skolens tilstand efter hans skøn lod en del tilbage at ønske. Skolen lider, skrev han, under den nuværende tingenes tilstand, ,idet både sproget og mandens alder (han går mod de 80) lægger hindringer $\mathrm{i}$ vejen for en levende undervisning og en energisk optræden blandt den opvoxende generation“. Udtalelsen må vel forstås derhen, at det kneb med disciplinen og med færdigheden i det danske. Bech ønskede egentlig derfor Knutz, der var over de 70, erstattet med en anden lærer. Han betonede dog, at hans afsked burde ske på en for ham hædrende måde og således, at hans fremtid sikredes ham, uden at sognet bebyrdedes, så han blev en persona ingrata $i$ sin øvige levetid.

Knutz selv var imidlertid meget uvillig over for den tanke at søge sin afsked og havde også af provsten engang fået løfte om at blive i embedet til sin død. Foreløbig hjalp man sig da 
med en substitut, og fra september 1858 indskrænkedes Knutz' undervisning til kun at gælde de 4 ugentlige timer i tysk. I kirkevisitatorernes beretninger 1859 og 1860 hører vi både om, hvor højst nødig Knutz vil pensioneres, og om, hvor ønskeligt det vilde være for skolen, om der skete en forandring. Det er ofte forbundet med store vanskeligheder at forskaffe ham en seminarist, hedder det, eller, når en sådan er erhvervet, at beholde ham i længere tid, og uden en seminarist som medhjælper vil det hele ikke gå.

Endelig i oktober 1862 - i en alder af godt 75 år - indvilgede Knutz $i$ at indgive sin afskedsbegæring til ministeriet mod en årlig pension af $400 \mathrm{rdl}$. „Skønt jeg nødig forlader det hus, hvori jeg i næsten over 49 år har havt et kært hjem og under min lange embedsvirksomhed har oplevet både onde og gode dage, så vil jeg dog gerne efterkomme kirkevisitatoriets anmodning“, skriver han. Kirkevisitatoriet anbefalede, at ministeriet ydede støtte til pensionen, så kommunen ikke bebyrdedes for stærkt, og sidst i marts 1863 ordnedes sagen også på denne maade. Knutz fik således sin afsked med fuld honnør. Han døde i januar 1870 og ligger begravet i Stenbjerg, medens hans enke først døde i den høje alder af 95 år i 1887 i Rinkenæs.

Kirkevisitatoriet havde sammen med sin erklæring fremsendt Stenbjerg skolekrønike med dens, som visitatoriet udtaler, fyldige og tilforladelige billede af en mand, „der, skønt kun beklædende en simpel og ubemærket stilling, indtager en høj plads blandt de trosindede mænd, der i farens dage har værnet om kongens og fædrelandets retfærdige sag i Sønderjylland“.

\section{Kilder.}

En afskrift af Knutz' beretning findes i Regenburgs samlinger i rigsarkivet i læg $10 \mathrm{i} \mathrm{pk}$. A. Samlinger til belysning af politiske og administrative forhold i Slesvig (og Holsten) til 1864 I. Ved gengi- 
velsen er tegnsætningen moderniseret og retskrivningen lempet efter den nuværende. Endvidere er en del af de ikke få germanismer fjernede.

Endvidere er benyttet visitationsberetningerne i slesvigske ministeriums arkiv (i rigsarkivet), sagen om Knutz' afskedigelse (slesv. min. 3. dpt. journ. nr. 925/1862) samt breve fra provst Aleth Hansen og pastor H. Bech til Regenburg (i dennes arkiv i rigsarkivet). Enkelte oplysninger stammer fra folketællingerne. D $\varnothing$ dsårene for Knutz og hans enke er mig meddelte af min kollega, arkivar P. Kr. Iversen.

I *Thyras Vold « 15. juni 1945 (nr. 296) oplyser A. Holst Jørgensen, at gulduret, som Knutz fik i 1858, stadig er i familiens besiddelse (ejet af en ætling i Bovrup). Sml. Holst J $\emptyset$ rgensens artikel i »Thyras Vold $\propto$ 15. juni 1944 (nr. 284): "Om hundred' Aar — - 